\title{
CURRENT MEASURES AGAINST OPHTHALMIC COMPLICATIONS OF DIABETES MELLITUS-A SHORT REVIEW
}

\section{MANORMA, RUPA MAZUMDER*, ANJNA RANI, RAJAT BUDHORI, AYUSHI KAUSHIK}

Noida Institute of Engineering and Technology (Pharmacy Institute), 19, Knowledge Park-2, Institutional Area, Greater Noida, Uttar Pradesh 201306, India

Email: rupa_mazumder@rediffmail.com

Received: 09 Aug 2021, Revised and Accepted: 04 Oct 2021

\begin{abstract}
Diabetes mellitus (DM) is a metabolic disorder, whose prevalence is predicted to rise shortly. The present review focuses on the various ocular complications associated with DM, and the various ophthalmic formulation approaches developed to treat the same. Diabetic macular edema (DME), diabetic retinopathy, cataracts, and glaucoma are some of the major vision-threatening complications linked to DM. The ocular route of drug delivery has undergone several advancements in recent decades, the introduction of various novel drug delivery systems (DDS), various modifications in the existing formulation approaches, development of custom-designed personalized medications, being some of the major developments introduced in the field of ocular drug delivery. Due to the application of state-of-the-art technologies in the field of innovations related to ocular DDS, patients have been immensely benefited by the current modes of ocular treatment imparting fewer side effects, enhanced penetration, sustained drug effect, and so on. The present review includes and emphasizes the gradual development that has occurred from the conventional ophthalmic dosage forms to the currently reported novel ocular drug delivery approaches along with the related clinical research works.
\end{abstract}

Keywords: Ophthalmic formulations, Diabetes mellitus, Ocular complications, Cataracts, Glaucoma, Diabetic retinopathy, Macular edema

(c) 2021 The Authors. Published by Innovare Academic Sciences Pvt Ltd. This is an open access article under the CC BY license (https://creativecommons.org/licenses/by/4.0/) DOI: https://dx.doi.org/10.22159/ijap.2021v13i6.42876. Journal homepage: https://innovareacademics.in/journals/index.php/ijap

\section{INTRODUCTION}

Diabetes has affected approximately 285 million people around the world to date. According to the International Diabetes Federation, this number is predicted to rise to 439 million by 2030 [1]. In 1997, the American Diabetes Association (ADA) has reported the categorization scheme for type 1 (insulin-dependent), Type 2 (insulin-dependent), and gestational diabetes mellitus (GDM), which have now been approved by the FDA also [2]. Diabetes mellitus (DM) is a metabolic disorder caused by the lack of insulin production, insulin activity, or both. Further, chronic hyperglycemia is caused by insulin insufficiency, impairing carbohydrate, lipid, and protein metabolisms $[3,4]$. It is one of the leading global health issues that have arisen as a chronic non-communicable disease (CNCD). The major complications associated with DM, include cataracts, glaucoma, diabetic retinopathy (DR), and diabetic macular edema [5]. It also sometimes leads to amputation of limbs, blindness, and vascular brain diseases [3]. Further, due to the occurrence of longterm hyperglycemia, the basement membrane of the eye accumulates enough toxic products, which cause irreversible damage to ophthalmic cells leading to cell death, ophthalmic opacity, and finally, vision impairment [4].

The present review has highlighted the development of various types of eye complications associated with diabetes, like diabetic cataracts, macular edema, formation of diabetic retinopathy and few others. It has also elaborated the methods of prevention of various ophthalmic complications resulting from diabetes, the development of various conventional and novel formulations used for the treatment of the same, as well as the associated clinical studies reported till date. The review has resulted from a thorough search on the literature available on the matter since 1969.

\section{Ocular complications associated with DM}

\section{Diabetic cataracts}

This disease is the most prevalent cause of blindness in the world, as it arises when the natural lens of the eyes becomes obscured, and hence, light does not move clearly through the latter, with the development of cataracts, finally resulting in loss of vision, if not treated at the early stage of its development. The lens clouding and development of cataracts are caused by unwanted protein aggregation on the lens due to prolonged, and uncontrolled persistence of DM $[6,7]$. The diabetics are reported to be five times more prone to get cataracts, especially at a young age. As the duration of diabetes increases, the chance of the development of diabetic cataracts also increases [8].

\section{Glaucoma}

The term glaucoma refers to a group of eye illnesses that affects the optic nerves. Diabetic patients are twice as likely to develop glaucoma, which can cause loss of vision, and the development of blindness, if not treated early [9]. Various types of glaucoma have been reported during the last few decades. They are as follows:

\section{Open-angle glaucoma (OAG)}

Diabetes mellitus has been linked to an increased risk of OAG in various studies. The risk factors associated with DM causing OAG, include the development of high intraocular pressure (IOP), vascular abnormalities, such as malformed optic nerve vessels, and oxidative damages to the eye. It has been reported that the probability of developing $\mathrm{OAG}$ increases with the uncontrolled prolongation of type 2 DM. The disease has been reported to be painless, persistent, and asymptomatic at its early stages of development. In the advanced stages of the disease, the resistance imparted by the developed trabecular meshwork to the aqueous outflow within the eye, gradually increases, resulting in a gradual increase in IOP [10].

\section{Closed-angle glaucoma (CAG)}

In CAG, the access to the drainage route from the eye is obstructed, resulting in the development of severe local pain, redness of the eye, nausea, and hike in IOP $[10,11]$.

\section{Neovascular glaucoma (NVG)}

This type of glaucoma is associated with the development of new blood vessels in the eye, obstructing the normal flow of ophthalmic fluid, thereby causing a rise in intraocular fluid pressure [12]. It is quite difficult to treat this type of condition of the eye by usual treatment with medicines, thus categorizing NVG as an uncommon kind of glaucoma [10]. 


\section{Diabetic retinopathy}

It is a common condition with diabetics, in which the blood vessels in the retina swell up, leak, or become completely obstructed due to impaired blood sugar regulation. There may also be the development of new ophthalmic blood vessels growing gradually on the surface of the retina [13].

\section{Diabetic macular edema}

Diabetic macular edema (DME) occurs when fluid accumulates on the retina, causing local swelling and distorted vision, ultimately resulting in permanent loss of vision. Diabetes-related vision loss can be averted in around $90 \%$ of instances, according to the Centres for Disease Control and Prevention (CDC) [4].

Thus, DM and its associated long-term ophthalmic complications have been the primary reasons for blindness for the last few decades, and surgical removal has been the only treatment available for the removal of diabetic cataracts $[13,14]$. Recently, the development of various novel and targeted drug delivery approaches and custom-designed personalized medications has made it possible to delay and retard the process of development of various types of ocular complications resulting from DM [15].

\section{Pathogenesis of ocular complications}

\section{Pathogenesis of diabetic cataracts}

During prolonged DM, the enzymes aldose reductase, and sorbitol dehydrogenase, present in the ophthalmic lens, transform glucose into sorbitol, causing glutathione deficiency, resulting in the formation of cataracts [16]. The formation of AGE (advanced glycation end-products), and the activation of the polyol pathway help the ophthalmic cells to accumulate sorbitol [17]. Another mechanism of cataracts formation involves induction of lens protein oxidation, production of free radicals, and hydrogen peroxide [16].

It has been reported that three processes are involved in the formation of diabetic cataracts, viz., the polyol pathway, nonenzymatic glycation, and oxidation [18].

\section{Polyol pathway}

In the polyol pathway (fig. 1), two enzymes are involved, viz., aldose reductase (AR), and sorbitol dehydrogenase ( $\mathrm{SDH}$ ). The former is responsible for the conversion of glucose to sorbitol, while the latter converts sorbitol to fructose. Osmotic, oxidative, glycation, and protein kinase-C (PKC) stresses are the principal cell-damaging effects of excessive intracellular glucose flux developed via the polyol pathway. The loss of NADPH, a co-factor in the reducing pathway, mediated by aldose reductase, is thought to produce oxidative stresses, resulting in a reduction in the antioxidant capacity of the cells [19]. Glycation of lens proteins is also caused by the increased glucose levels in the aqueous humor, which results in the generation of superoxide radicals $\left(\mathrm{O}_{2}-\mathrm{J}\right.$, and advanced glycation end products (AGE) [20]. The advanced glycation end products then interact with the advanced glycation receptors and lens epithelial material [21]. The most prevalent antioxidant enzyme in the lens is superoxide dismutase (SOD), which breaks superoxide radicals $\left(\mathrm{O}_{2}\right.$-) into $\mathrm{H}_{2} \mathrm{O}_{2}$, and $\mathrm{O}_{2}$ [22]. Another mechanism involved in the production of 3-deoxyglucosone, a key precursor to the development of AGEs [23]. The sorbitol dehydrogenase enzyme enhances the elimination of dihydroxyacetone phosphate by increasing the NADH: NAD+ratio, a precursor for conversion of diacylglycerol (DAG) to glycerol-3-phosphate, which can produce PKC stress [24, 25].

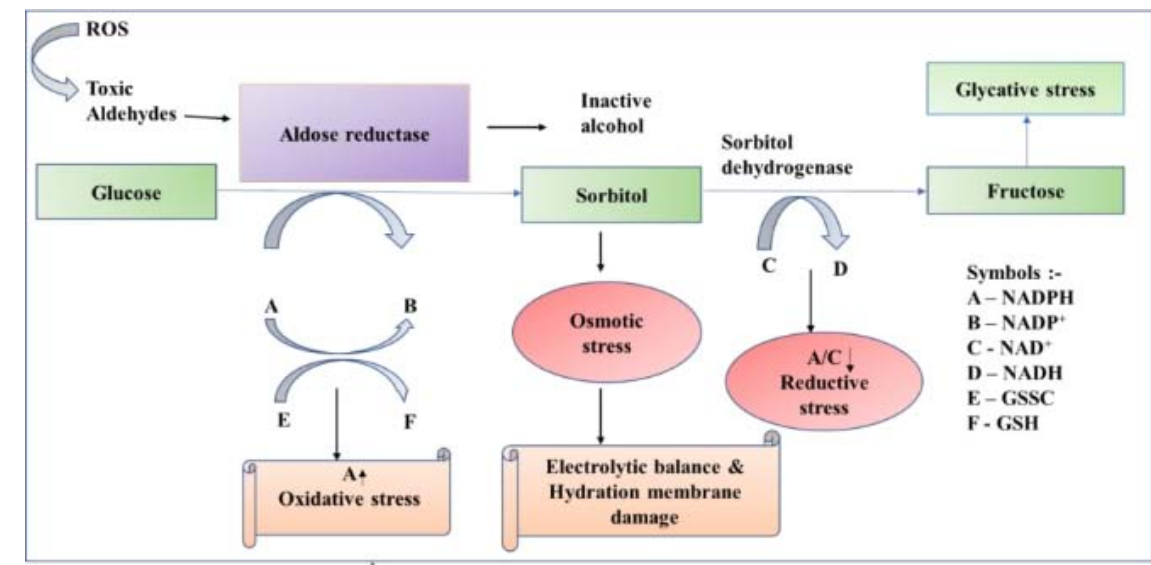

Fig. 1: Aldose reductase and polyol pathway [19], [NADPH: Nicotinamide adenine dinucleotide phosphate; NAD+: Nicotinamide adenine dinucleotide; NADP+: Oxidized nicotinamide adenine dinucleotide phosphate; NADH: Reduced nicotinamide adenine dinucleotide; GSSG: Oxidized glutathione; GSH: Reduced glutathione]

\section{Non-enzymatic glycation}

One of the well-known mechanisms implicated in diabetes cataracts with age, is non-enzymatic glycation, in which advanced glycation end products pile up, causing opacity of lens [26]. Advanced glycation is caused by a non-enzymatic interaction between excess glucose and proteins, which can result in the creation of superoxide radicals, and AGEs [27].

\section{Oxidation}

The effects of oxidative stress on diabetic lens fibers, generated by the free radicals, have been studied in several types of recent researches. There isn't any proof, however, that the process of cataracts formation is initiated by these free radicals, but it rather accelerates and aggravates its growth. The aqueous humor of diabetics contains high levels of hydrogen peroxide $\left(\mathrm{H}_{2} \mathrm{O}_{2}\right)$, which causes hydroxyl radicals $\left(\mathrm{OH}^{-}\right)$to develop after entering the lens through a mechanism known as Fenton reactions [28]. Another component that is increasingly deposited on diabetic lenses, and aqueous humor, is the free radical nitric oxide (NO) Because of its oxidizing properties, it can cause an increase in the formation of peroxynitrite, which further causes cell damage [29].

\section{Pathogenesis of glaucoma}

The secretion of aqueous humor from the ciliary body, and drainage of the former through two distinct routes, the trabecular meshwork and the uveoscleral outflow pathway, regulate the intraocular pressure (the pressure inside the eye), the increase of which has been the key feature in the development of glaucoma. Diabetes mellitus also has been linked to a variety of glaucoma conditions, including open-angle glaucoma (OAG), angle-closure glaucoma (CAG), and neovascular glaucoma (NVG) [30, 31].

Several common links have been established and explained to contribute to the possible correlation between diabetes and glaucoma [32]. Diabetes or hyperglycemia is associated with lipid 
glycation, and lipid metabolism disorders, which can lead to increased intraocular pressure (IOP), vascular dysfunction, oxidative damage, excitotoxic damage, and so on (fig. 2). The malfunction, and death of retinal ganglion cells (RGCs) in glaucomatous eyes, cause permanent loss of vision [33, 34]. Vascular dysregulation, as well as elevation of nitric oxide, a potent vasodilator, have been observed in both the disorders, diabetic eye disease, and glaucoma. Nitric oxide is not only a well-known regulator of vascular tone but also causes apoptosis [35]. Furthermore, it has been reported that reactive nitrogen species play a significant role in inflammatory reactions through oxidative stresses, resulting in the damage of optic nerves [36]. The elevation of protein kinase $\mathrm{C}$ may also be linked to matrix metalloprotease trabecular meshwork abnormalities, which may result in impaired aqueous outflow and higher IOP [32]. Furthermore, overexpression of the metalloprotease- 9 matrix has been linked to structural abnormalities in the optic nerve head in diabetic individuals, suggesting yet another probable link between diabetes, and glaucoma $[37,38]$.

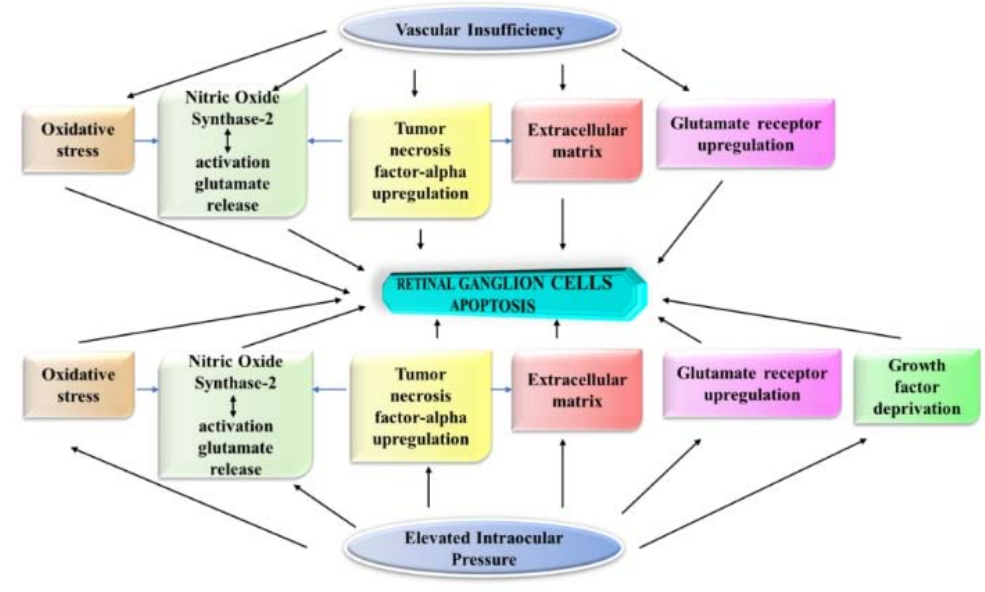

Fig. 2: Systematic representation of various factors leading to glaucoma [30]

\section{Pathogenesis of diabetic retinopathy and diabetic macular edema}

As described in (fig. 3), hyperglycemia leads to the generation of free radicals (oxidative stress), activation of protein kinase $C$, and formation of advanced glycation end products (AGEs), which may trigger the development of DR, and maculopathy [39]. Disruption of the blood-retinal barrier (BRB) is important in the pathogenesis of diabetic macular edema; the altered vitreomacular interface may also play a role in the progression of macular edema. Other factors connected to the progression of DME, include hypoxia, reduced blood flow, retinal ischemia, and associated inflammation [40]. Inflammatory processes are upregulated within the diabetic retinal vasculature, such as increase in the vascular endothelial growth factor (VEGF) levels, endothelial dysfunction, leukocyte adhesion, decrease in the levels of pigment epithelium-derived factor (PDF), and increased development of protein kinase $C$, causing BRB breakdown, and increased vascular permeability [40-42] Historically, DR has been thought to be caused by retinal capillary microvascular injury. However, there is mounting evidence that retinal neural failure occurs before vascular problems [43]. Neurodegeneration, neuroinflammation, and activation of RAS (renin-angiotensin system) have been identified as the important factors responsible for the development of DR [44]. Furthermore, both the stress in the endoplasmic reticulum (ER) and the abnormal production of mitochondria-derived reactive oxygen species play an important role in the development of DR [45]. As the unfolded protein response is unable to reduce ER stress, it contributes to increased oxidative damage, inflammation, and apoptosis in the ER lumen. All these are likely to play a significant role in the development of a variety of neuronal diseases in the brain, and retina, thereby aggravating DR from its early stage [46].

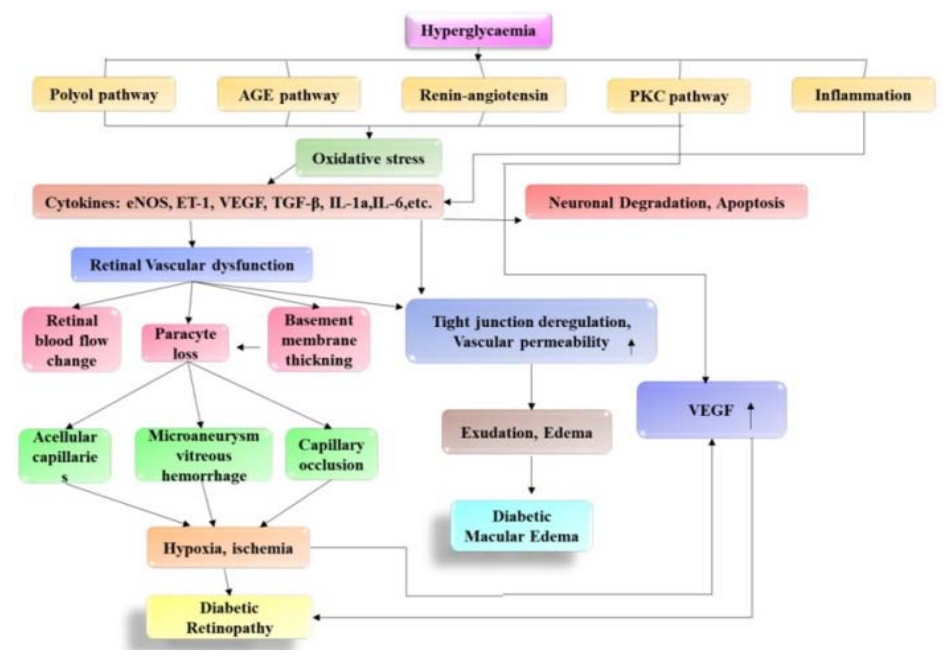

Fig. 3: Pathophysiology of DR and DME [41], [AGE: Advanced glycation end-product; PKC: Protein Kinase C; eNOS: Endothelial nitric oxide synthase 3; ET-1: Endothelin-1; VEGF: Vascular endothelial growth factor; TGF- $\beta$ : Transforming growth factor-beta; IL-1a: Interleukin 1 alpha; IL-6: Interleukin 6] 


\section{Prevention and treatment of ocular complications}

\section{Prevention and treatment of diabetic cataracts}

The following categories of dietary phytochemicals and synthetic compounds are generally used to obtain the desired therapeutic effect against diabetic cataracts. These compounds are used as lowcost, non-surgical cataract preventive measures, which are the need of the day (fig. 4) [47]. The conventional and novel drugs available for ocular complications have been depicted in tables 1 and 2, respectively.

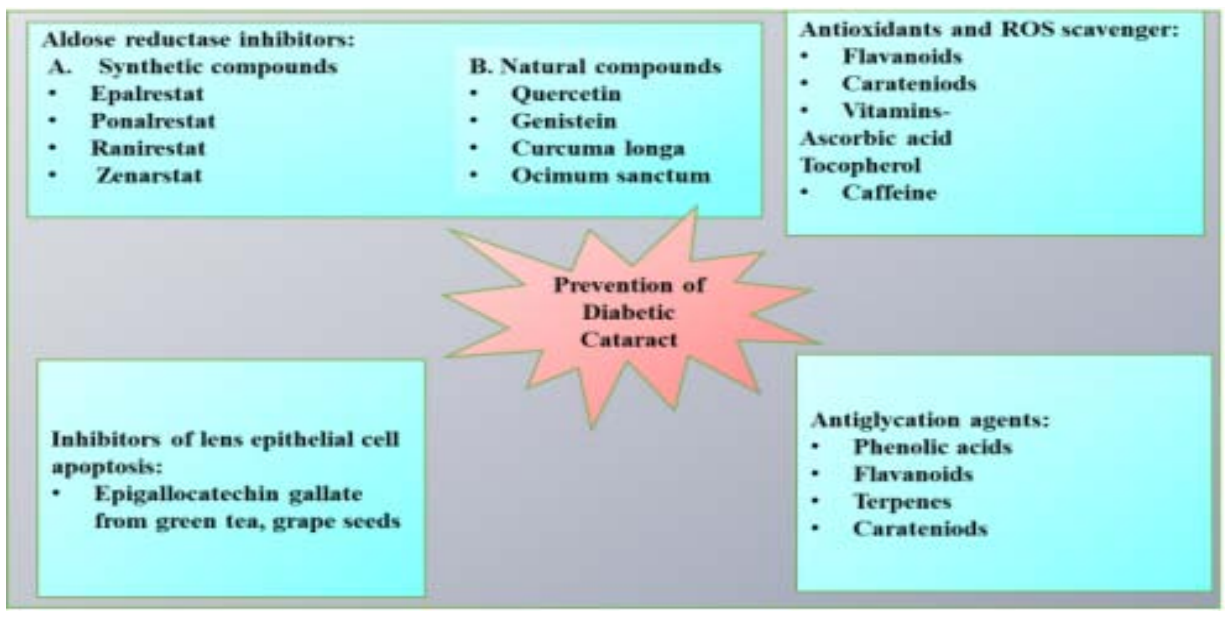

Fig. 4: Treatment available for diabetic cataracts $[7,49,51]$

\section{Aldose reductase inhibitors (ARIs)}

Some promising ARIs with significant potential for the treatment of diabetic cataracts have been discovered in recent decades $[48,49]$. The ongoing researches in the field of natural products have revealed evidence confirming that certain bioactive compounds can help to slow or stop diabetic problems from getting worse. These compounds also have significant in vitro as well as in vivo inhibitory effects on aldose reductase, the enzyme responsible for the conversion of glucose to sorbitol, resulting in the deposition of diabetic cataracts.

The ARIs derived from natural sources include a range of structurally distinct compounds mostly belonging to the flavonoid category $[50,51]$. Quercetin and genistein are two examples of such flavonoid compounds that slow the progression of the development of diabetic cataracts [51, 52]. Extracts from various indigenous herbs, often known as Indian Herbal Diabecona, such as Ocimum sanctum, Withania somnifera, Curcuma longa, and Azadirachta indica, have shown to support the ARI's role in preventing and delaying the progression of cataracts [53, 54]. Moreover, some synthetic ARIs, viz., alrestatin, imprestat, ponalrestat, epalrestat, zenarestat, and lidorestat have also been reported for their positive effects on the prevention of diabetic cataracts [55]. Amongst these, only epalrestsat has been introduced into the market for the treatment of diabetic neuropathy [56]. These findings offer the basis for the possible potential prophylactic as well as therapeutic use of ARIs against diabetic cataracts [57].

\section{Antioxidants and ROS scavengers}

Antioxidant drugs and ROS scavengers may be useful since oxidative damage occurs indirectly as a result of polyol accumulation during the formation of diabetic cataracts. A variety of antioxidants have been found to delay cataracts formation in diabetic mice [58]. These include alpha-lipoic acid, ascorbic acid, vitamin E, and carotenoids, all of which have been evaluated, and confirmed to protect against diabetic cataracts $[58,59]$. The most commonly used antioxidant enzymes include superoxide dismutase (SOD), and glutathione peroxidase to be used in the ophthalmic lens. These enzymes break down the superoxide radicals into $\mathrm{H}_{2} \mathrm{O}_{2}$, and oxygen $\left(\mathrm{O}_{2}\right)$ [61]. In several in vitro, and in vivo studies, SOD has been shown to protect against cataracts formation during DM [62].

\section{Inhibitors of lens epithelial cell apoptosis}

Apoptosis is a normal process of cell death that provides a physiological foundation for cataracts initiation and progression
[63]. Depending on the nature of many apoptotic stimuli, the mechanisms involved in cell apoptosis are classified as intrinsic or extrinsic pathways. Oxidative stress, and mitochondrial damage, and dysfunction have been identified as important mediators of apoptosis in the epithelial cells of an ophthalmic lens, and they play a key role in the pathogenesis of cataracts [63, 64]. Grape seed extracts, resveratrol, and coenzyme Q10 (ubiquinone) are few examples of the reported inhibitors of epithelial cell apoptosis, all of which being operating as free radical scavengers, thereby reducing the development of ROS, increasing the defense against oxidative stress, and avoiding light-induced apoptosis of the epithelial cells [59,65-68].

\section{Antiglycation agents}

Advanced glycation occurs in diabetic patients, but to a larger extent than that in normal aging, leading to the development of lens opacity [69]. The clinically used antiglycation agents also serve as potential anticataract agents, such as the naturally bioactive molecules like the polyphenols, phenolics, flavonoids, terpenes, carotenoids, polyunsaturated fatty acids, and synthetic compounds like aspirin, ibuprofen, aminoguanidine, and pyruvate [70-72]. The most prevalent component of green tea (Camella Sinensis) is epigallocatechin gallate (EGCG), which has strong antioxidant capabilities and also reduces the generation of $\mathrm{H}_{2} \mathrm{O}_{2}$ [7].

\section{Prevention and treatment of glaucoma}

\section{Adrenergic agonists}

Adrenergic agonists (norepinephrine), the primary neurotransmitters of the adrenergic system, produced by activation of the alpha, and/or beta receptors, have the potential for the treatment of glaucoma [73]. At the moment, the most well-known example is brimonidine, a selective alpha-2 receptor agonist that has been reported for its use in the treatment of glaucoma [74-76].

\section{$\beta$-receptor antagonists}

By lowering intracellular cAMP levels, antagonists of $\beta$-receptors, which are found in the eye, inhibit the production of aqueous humor in the ciliary body [77]. Timolol has been the first anti-glaucoma drug to receive FDA approval, and it has been the most popular drug treating glaucoma for many years. Betaxolol, carteolol, metipranolol, and levobetaxolol have been amongst the first beta-receptor antagonists to hit the market, each with slightly distinct pharmacological features [78]. 


\section{Carbonic anhydrase inhibitors}

Topical carbonic anhydrase inhibitors prevent the formation of aqueous humor, thereby preventing the increase in IOP [79]. Brinzolamide and dorzolamide are two such drugs that have been used for lowering IOP. Acetazolamide, a systemic carbonic anhydrase inhibitor, is one of the most effective IOP-lowering medications now available on the market [80].

\section{Parasympathomimetics}

By extending the trabecular meshwork, and Schlemm's canal, the parasympathomimetics cause smooth muscle cells in the ciliary body to contract, enhancing the outflow of aqueous humor [78]. The most well-known member of this class of antiglaucoma medications that can lower IOP is pilocarpine [81].

\section{Prostaglandin analogs}

Prostaglandin analogs connect to the prostaglandin F (FP) receptors, thereby increasing the uveoscleral outflow. As a result, the ciliary muscle expands and the tissue-filled spaces along the ciliary muscle bundles are decompressed, releasing the IOP. Bimatoprost, latanoprost, tafluprost, and travoprost are some of the currently available prostaglandin analog drugs considered for first-line treatment of glaucoma [82].

\section{Prevention and treatment of diabetic retinopathy and diabetic macular edema}

Corticosteroids have been shown to have anti-inflammatory and anti-angiogenetic properties via modulating pro-inflammatory mediators, such as tumor necrosis factor-alpha (TNF- $\alpha$ ), interleukin1 (IL-1), and VEGF [83]. The levels of these mediators increase, as the disease progresses. For DME and DR, corticosteroid medication is a popular treatment option [84]. In the treatment of DME, and DR systemic corticosteroid therapy may be an effective adjunct to laser photocoagulation. Intravitreal triamcinolone acetonide (IVTA) has been shown to have anti-inflammatory properties and can aid in the treatment of DME. Because of its potent antiangiogenic effects, IVTA can also help to reduce PDR $[84,85]$.

\section{Corticosteroid therapy with the sustained delivery system}

Triamcinolone acetonide (TA) implant is one of these delivery mechanisms for DME [85]. Fluocinolone acetonide nonbiodegradable intravitreal insert is another sustained drug delivery mechanism that attempts to release fluocinolone over three years. This approach is usually thin and allows for direct injection into the back of the eye through a self-sealing opening, which is under processing of FDA approval for future commercialization [83]. Ozurdex (allergen), a sustained-release biodegradable, intravitreal implant, and used for the treatment of macular edema, has also been authorized by the FDA. In phase I clinical trial with several openlabel and dose-escalation scenarios, NOVA63035 (intravitreal injection of dexamethasone palmitate) is now being examined in patients with DME to determine its safety, and tolerability [86]. Clinical experiments for the sustained-release delivery of TA, are presently using Verisome technology (IBI-20089) [83, 87].

\section{Other non-steroidal anti-inflammatory agents}

Other nonsteroidal anti-inflammatory drugs (NSAIDs) have been licensed by the FDA for the treatment of DR, and DME. Nepafenac, a topical nonsteroidal medication that is beneficial in the treatment of DME, is one of them [88]. Clinical studies for nepafenac are presently underway. Anatomic and functional improvements were seen after systemic treatment of DME with intravitreal infliximab injection [89].

\section{Antiangiogenic agents}

In addition to corticosteroids, antiangiogenic drugs are beneficial in the treatment of PDR, and DME. The vascular endothelial growth factor (VEGF) subfamily protein, which has been linked to the development of DR, and age-related macular edema degeneration (AMD) [83], is the primary target of these antiangiogenic agents. Bevacizumab is a humanized full-length antibody that targets all kinds of VEGF [90]. Exudative AMD is treated with ranibizumab, the FDA approved a recombinant humanized antibody fragment that targets VEGF-A in 2006 [91, 92]. JSM6427 ( $\alpha 5 \beta 1$-fibronectin), a German biopharmaceutical company's developed antiangiogenic compound, has shown promising results in reducing DR. JSM6427 is now undergoing a phase I clinical trial [93]. GlaxoSmithKline developed Pazopanib, an antiangiogenic drug that is taken orally. VEGF receptor (VEGFR), platelet-derived growth factor receptor (PDGFR), and tyrosine-protein kinase KIT (c-kit) are all targets for this drug. It is now being investigated for safety, efficacy, and tolerability in phase III clinical trials [94].

\section{Vitreous agents}

Vitrase is the first, and only ovine hyaluronidase that is free of preservatives and thimerosal. Its application as a spreading agent has been authorized by the FDA. A phase III clinical trial is underway to see if it can treat PDR-induced ocular hemorrhage [95]. Microplasmin is another vitreous agent that is injected intravitreally. It has been suggested that generating posterior vitreous detachment can be employed to treat DME, and PDR. for example, ThromboGenics NV [96].

\section{The potential use of systemic agents to treat diabetic retinopathy}

Many drugs used to treat dyslipidemia, and hypertension in diabetic individuals have been shown to decrease the advancement of DR [88].

Hypoglycemic agent-Insulin therapy, Thiazolidine

Hypolipidemic agent-Fibrates (fenofibrate)

Statin-Atorvastatin

Antiplatelets-Dipyridamole, Aspirin

\section{Potential plant-based drugs}

Plant-based therapies have also been shown to be useful in the treatment of DR. Because of their efficacy, ability to generate hypoglycemic effects, and renoprotective qualities, plant-based medicines are utilized to treat DR illness. One of the metabolic processes that contribute to DR development is the activation of the polyol pathway $[97,98]$.

This route is responsible for metabolizing excess glucose in diabetics. Ocimum sanctum, Tinospora cordifolia, Azadirachta indica, Ganoderma lucidum, and other plants contain AR inhibitors. Ocimum sanctum protects against DR when combined with vitamin E [97]. Tinospora cordifolia protects against DR by reducing oxidative stress in the retina caused by increased levels of proangiogenic, and proinflammatory mediators [98]. The fungus Ganoderma lucidum protects the retina against oxidative damage [99]. Curcumin is a plant-derived medication that has been shown to diminish DR progression in a rat model by suppressing retinal VEGF overexpression [100]. Curcumin, through antioxidant, and antiinflammatory mechanisms, reduced the thickness of the basement membrane in the retina of treated rats [101]. Hesperetin has also been shown to aid in the prevention of DR transmission [102]. Other antioxidant-rich compounds, including quercetin, and rosmarinic acid, have been shown to decrease angiogenesis and so diminish DR $[103,104]$.

\section{Antioxidants as a potential therapeutic agent}

It has been discovered that $\mathrm{N}$-acetylcysteine (NAC), vitamin $\mathrm{C}$, and lipoic acid are involved in reducing diabetic complications [105, 106]. Calcium dobesilate has been demonstrated to lower retinal permeability and VEGF expression. Caffeic acid is an antiangiogenic medication that inhibits the development of reactive oxygen species (RAS), and the production of VEGF in retinal cells [107]. Lipoic acid suppresses apoptosis while also reducing nitrotyrosine buildup and NF-B activation [108]. Rosmarinic acid, Benfotiamine, Pycnogenol, Curcumin, Taurine, and green tea have all been shown to have free radical scavenging properties and have all been used to treat DR [109-111].

The medications tested in clinical trials to treat an eye problem associated with diabetes have been enlisted in tables 3 . 
Table 1: Conventional drugs available for diabetic ocular complications

\begin{tabular}{|c|c|c|c|}
\hline Disease & Formulation & Plant/Drug & Reference(s) \\
\hline Cataracts & Eye drop & Boerhaavia diffusa root & [112] \\
\hline Cataracts & Eye drop & Calcium dobesilate & [113] \\
\hline Cataracts & Eye drop & $\begin{array}{l}\text { Polyherbal formulations (Tinospora cardifolia, } \\
\text { Cinnamomum zeylanicum, Curcuma longa, Trigonella } \\
\text { foenum graecum, Azadirachta indica, Piper nigrum) }\end{array}$ & {$[114]$} \\
\hline Cataracts & In situ gel & Boerhaavia diffusa root & [112] \\
\hline Macular edema & Eye drop & Dexamethasone & [115] \\
\hline Macular edema & Tablet & Curcumin & [116] \\
\hline Cataracts & Eye drop & Naproxen & [116] \\
\hline $\begin{array}{l}\text { Diabetic retinopathy (DR), diabetic macular } \\
\text { edema (DME) and diabetic cataracts (DC) }\end{array}$ & Injection & Ranibizumab & [117] \\
\hline Cataracts & Eye drop & Abrus precatorius & [118] \\
\hline Cataracts & Eye drop & Aloe vera & [119] \\
\hline Cataracts & Paste & Byttneria herbacea & [120] \\
\hline Cataracts & Eye drop & Microglossa pyrifolia & [121] \\
\hline Glaucoma & Eye drop suspension & Acetazolamide & [122] \\
\hline Macular edema & Injection & Ranibizumab & [123] \\
\hline Macular edema & Eye drop & Epafenac & {$[124]$} \\
\hline Macular edema & Eye drop & Ketorolac & [125] \\
\hline Glaucoma & In-situ gel & Dorzolamide & [126] \\
\hline Glaucoma & Mini-tablet & Timolol maleate & [127] \\
\hline
\end{tabular}

Table 2: Novel formulations available for the treatment of diabetic ocular complications

\begin{tabular}{|c|c|c|c|c|}
\hline Disease & Drug & Novel approach & Description & Reference(s) \\
\hline Glaucoma & Brimonidine & Cubosomes & $\begin{array}{l}\text { Ex-vivo corneal permeation tests revealed that the improved formulation } \\
\text { had higher corneal permeability than the consumer product. }\end{array}$ & {$[128]$} \\
\hline Glaucoma & $\begin{array}{l}\text { Timolol } \\
\text { maleate, } \\
\text { Brimonidine }\end{array}$ & Hydrogel & $\begin{array}{l}\text { Because they may localize, and sustain pharmacological activity at the site } \\
\text { of action for prolonged periods, they have an additive effect on (IOP) } \\
\text { reduction. As a result, long-term activity is possible. }\end{array}$ & [129] \\
\hline Glaucoma & Brimonidine & Cubosomes & $\begin{array}{l}\text { By preparing or extending the mean residence time of BRT-loaded } \\
\text { cubosomes, improves the ocular bioavailability of BRT, and prolongs its } \\
\text { intraocular pressure-lowering action. }\end{array}$ & [128] \\
\hline Cataracts & Epalrestat & Hydrogel & This promises the aggregation, and diffusion of drugs across the cornea & [130] \\
\hline Glaucoma & $\begin{array}{l}\text { Ketorolac } \\
\text { Tromethamine }\end{array}$ & Cubosomes & $\begin{array}{l}\text { High transcorneal permeation, and corneal retention were observed with } \\
\text { cubosomal formulation corresponding to ketorolac solution and high } \\
\text { transcorneal permeation, and retention, showing a biphasic release profile. }\end{array}$ & {$[121]$} \\
\hline Glaucoma & Timolol maleate & Cubosomes & $\begin{array}{l}\text { For traditional eye drops, Cubogel may be a successful option, since it } \\
\text { maintained the release of the medication for a longer time, and could also } \\
\text { minimize the number of drug applications. }\end{array}$ & [132] \\
\hline $\begin{array}{l}\text { Macular } \\
\text { edema }\end{array}$ & $\begin{array}{l}\text { Triamcinolone- } \\
\text { acetonide }\end{array}$ & Liposomes & $\begin{array}{l}\text { Patients with refractory macular edema were able to tolerate the } \\
\text { treatment and see an improvement in their best-corrected visual acuity, } \\
\text { and central foveal thickness. }\end{array}$ & [133] \\
\hline Glaucoma & Latanoprost & Liposomes & $\begin{array}{l}\text { Best-corrected visual acuity is well-tolerated, enhanced, and sustained in } \\
\text { vitro release of central foveal A ( } 60 \%) \text { was achieved over } 14 \mathrm{~d} \text {. For } 90 \mathrm{~d} \text {, a } \\
\text { subconjunctival liposome injection reduced IOP in rabbit eyes ( } 4.81 .5 \mathrm{~mm} \\
\mathrm{Hg} \text { ) compared to topical daily latanoprost treatment }(2.50 .9 \mathrm{~mm} \mathrm{Hg}) \\
\text { without causing ocular discomfort. }\end{array}$ & {$[134]$} \\
\hline Glaucoma & Brinzolamide & Liposomes & $\begin{array}{l}\text { With a lipid/cholesterol ratio of } 7: 4 \text {, and a lipid/drug ratio of } 10: 1 \text {, optimal } \\
\text { liposomes had an EE of } 98.321 .61 \% \text { and a diameter of } 84.332 .02 \mathrm{~nm} \text {. } \\
\text { Liposomes ( } 1 \mathrm{mg} / \mathrm{ml} \text { ) demonstrated a } 6.2 \text { fold increase in the coefficient of } \\
\text { corneal permeability and a more continuous and effective decrease of IOP } \\
\text { in rabbits' eyes ( } 5-10 \mathrm{~mm} \mathrm{Hg}) .\end{array}$ & [135] \\
\hline Glaucoma & $\begin{array}{l}\text { Dorzolamide } \\
\text { hydrochloride }\end{array}$ & $\begin{array}{l}\text { In situ gelling } \\
\text { polymeric } \\
\text { nanoparticles }\end{array}$ & $\begin{array}{l}\text { Optimized nanoparticles }(164 \mathrm{~nm}, 98.1 \text { percent entrapment efficacy) } \\
\text { showed sustained in vitro release and slower corneal penetration }(35.5 \%) \\
\text { as compared to commercial eye drops }(86.34 \%) \text {. Nanoparticles were } \\
\text { mucoadhesive, non-irritating, and remained in rabbit eyes for a long time. }\end{array}$ & [136] \\
\hline Glaucoma & $\begin{array}{l}\text { Dorzolamide } \\
\text { hydrochloride }\end{array}$ & $\begin{array}{l}\text { Polymeric } \\
\text { nanoparticles }\end{array}$ & $\begin{array}{l}\text { When compared to Trusopt } ₫ \text {, nanoparticles showed a } 1.8-2.5 \text { fold } \\
\text { improvement in corneal penetration and a greater drug concentration in } \\
\text { the aqueous humor (1.5-2.3 fold). Vitamin E TPGS was found to be a safer } \\
\text { and more efficient emulsifier than PVA. It functions as an inhibitor of P- } \\
\text { glycoprotein (prominent eye tissue efflux transporters) and has induced a } \\
\text { substantial increase in the efficacy of trapping and corneal permeation. }\end{array}$ & [137] \\
\hline Glaucoma & $\begin{array}{l}\text { Betaxolol } \\
\text { hydrochloride }\end{array}$ & $\begin{array}{l}\text { Polymeric } \\
\text { nanoparticle }\end{array}$ & $\begin{array}{l}\text { A biphasic release pattern was found in optimized (1:2) polymer: drug } \\
\text { ratio nanoparticles, with an early burst followed by a persistent release } \\
\text { lasting up to } 12 \mathrm{~h} \text {. Nanoparticles demonstrated excellent ocular tolerability } \\
\text { and a considerable decline in IOP, with a high of } 9.90 .5 \mathrm{~mm} \text { Hg compared to } \\
\text { control after } 5 \mathrm{~h} \text {. }\end{array}$ & [138] \\
\hline
\end{tabular}




\begin{tabular}{|c|c|c|c|c|}
\hline Disease & Drug & Novel approach & Description & Reference(s) \\
\hline Glaucoma & Brimonidine & $\begin{array}{l}\text { Polymeric } \\
\text { nanoparticles } \\
\text { in preformed gel }\end{array}$ & $\begin{array}{l}\text { Due to adhesion to the negatively charged cornea, and conjunctiva, } \\
\text { optimized chitosan nanoparticles combined in prepared gel showed } \\
\text { greater sustained release over SA nanoparticles. Compared to eye drops, } \\
\text { cytotoxicity tests reported non-toxic formulations with a sustained } \\
\text { reduction of IOP }(>25 \mathrm{~h})\end{array}$ & [139] \\
\hline Glaucoma & Methazolamide & SLNs & $\begin{array}{l}\text { The Box-Behnken model was used to optimize SLNs with a size of } 197.84 .9 \\
\mathrm{~nm}, 68.39 \text { percent drug trapped, continuous-release following the Peppas } \\
\text { model, and a considerable extended reduction in IOP compared to } \\
\text { AZOPT® without any signs of ocular discomfort. }\end{array}$ & {$[140]$} \\
\hline Glaucoma & Brimonidine & SLNs; NLCs & $\begin{array}{l}\text { After autoclaving at } 121^{\circ} \mathrm{C} \text { for } 15 \mathrm{~min} \text {, both SLNs, and NLCs were } \\
\text { physically stable, yielding particles below } 500 \mathrm{~nm} \text { that were non-irritant to } \\
\text { the ocular mucosa, and had higher ZP, and brimonidine concentrations } \\
\text { collected than non-autoclaved ones. }\end{array}$ & {$[141]$} \\
\hline Glaucoma & Melatonin & Cationic SLNs & $\begin{array}{l}\text { As a positive charge imparter, didecyldimethylammonium bromide was } \\
\text { employed to create cationic SLNs that demonstrated high mucoadhesion, } \\
\text { extended ocular retention time, good tolerability, and was very successful } \\
\text { for } 24 \text { hour IOP reduction (maximum IOP reduction of } 7 \mathrm{~mm} \mathrm{Hg} \text { ) }\end{array}$ & [142] \\
\hline Glaucoma & Methazolamide & $\begin{array}{l}\text { Surface modified } \\
\text { SLNs by chitosan }\end{array}$ & $\begin{array}{l}\left.\text { In terms of particle stability ( } 4 \text { mo at } 4^{\circ} \mathrm{C}\right) \text {, size }(199.42 .8 \mathrm{~nm}) \text {, in vitro } \\
\text { release, and ocular penetration, chitosan-modified SLNs beat non-modified } \\
\text { SLNs. The peak reduction in IOP was better than both unmodified SLNs and } \\
\text { AZOPT® eye drops without any signs of ocular discomfort. }\end{array}$ & [143] \\
\hline Glaucoma & Latanoprost & Liposomal gels & $\begin{array}{l}\text { The best liposomes had a 7:3 lipid: cholesterol ratio and a 1:1 drug: lipid } \\
\text { ratio, with a trap performance of } 98 \text { percent. Latanoprost's interaction } \\
\text { with liposome excipients improved drug encapsulation. Vesicles are } \\
\text { incorporated into the Pluronic } ₫ \text { F } 127 \text { gel's continuous medication release } \\
\text { system ( } 45 \text { percent discharged in } 2 \text { d). Liposomal gels did not irritate the } \\
\text { eyes of rabbits. }\end{array}$ & [144] \\
\hline Glaucoma & Brinzolamide & Liposomes & $\begin{array}{l}\text { With a lipid/cholesterol ratio of } 7: 4 \text {, and a lipid/drug ratio of } 10: 1 \text {, optimal } \\
\text { liposomes had an EE of } 98.32 \% \text { and } 84.33 \% \text {, respectively, and a diameter } \\
\text { of } 1.61 \text { and } 2.02 \mathrm{~nm} \text {, respectively. In comparison to the commercial } \\
\text { solution }(10 \mathrm{mg} / \mathrm{ml}) \text {, liposomes }(1 \mathrm{mg} / \mathrm{ml}) \text { showed a } 6.2 \text { fold improvement } \\
\text { in corneal permeability and a more consistent, and stable lowering of IOP } \\
\text { in rabbit eyes ( } 5-10 \mathrm{~mm} \mathrm{Hg}) \text {. }\end{array}$ & [135] \\
\hline Glaucoma & Diltiazem $\mathrm{HCl}$ & $\begin{array}{l}\text { Unilamellar } \\
\text { vesicles }\end{array}$ & $\begin{array}{l}\text { The vesicles rigidified with cholesterol were the most stable at a } 1: 1 \text { molar } \\
\text { ratio. The addition of cholesterol improved the efficacy of the percent trap } \\
\text { while reducing the rate of drug release. Compared to the solution, an } \\
\text { improved IOP lowering operation was obtained in rabbit eyes. }\end{array}$ & [145] \\
\hline Glaucoma & Timolol maleate & $\begin{array}{l}\text { Liposome in } \\
\text { ion-sensitive in- } \\
\text { situ gel }\end{array}$ & $\begin{array}{l}\text { Liposomes having a diameter of } 136 \mathrm{~nm} \text {, a trapping efficiency of } 47 \\
\text { percent, and a corneal penetration augmentation of } 1.93 \text { times were found } \\
\text { to be the most effective. When compared to eye drops, in situ gel liposomes } \\
\text { beat commercial eye drops, and liposomes in terms of corneal retention } \\
\text { time were non-irritant to ocular tissues and show a rapid reduction in IOP. }\end{array}$ & [146] \\
\hline Glaucoma & $\begin{array}{l}\text { Timolol } \\
\text { maleate, } \\
\text { Dorzolamide } \\
\text { hydrochloride }\end{array}$ & $\begin{array}{l}\text { Nano-fiber } \\
\text { patches }\end{array}$ & $\begin{array}{l}\text { The formulation produced has very high mucoadhesive strength, so it can } \\
\text { be kept in the eyes for a longer time. } \\
\text { Besides, the formulation was able to sustain the IOP for up to } 72 \mathrm{~h} \text {. }\end{array}$ & [147] \\
\hline Glaucoma & Brimonidine & Inserts & $\begin{array}{l}\text { Ocular implants containing } 7 \% \text { PVP, and } 1.5 \% \text { SA with or without an } \\
\text { ethylcellulose layer were used to maintain brimonidine release in vitro } \\
(99 \% \text { at } 6 \mathrm{~h}) \text {. When injected into the eyes of albino rabbits, their } \\
\text { therapeutic efficiency in lowering IOP was found to be more long-lasting } \\
\text { than that of the brimonidine solution. There was a larger IOP lowering } \\
\text { effect with the two-sided coated ocular insert than with the one-sided } \\
\text { coated ocular insert. }\end{array}$ & [148] \\
\hline Glaucoma & Timolol maleate & Film & $\begin{array}{l}\text { The drug was ready in four weeks }(85 \% \text { released over the first } 2 \mathrm{w}) \text {. } \\
\text { During } 10 \mathrm{w} \text {, the film's drug release, on the other hand, reduced in vivo IOP } \\
\text { levels. Between rabbits given a } 0.5 \text { percent commercial ophthalmic } \\
\text { solution, and those treated with films, there was no significant difference in } \\
\text { IOP reduction }(\mathrm{P}<0.05) \text {. There was no sign of anxiety or ocular problems. }\end{array}$ & {$[144]$} \\
\hline Glaucoma & Latanoprost & Nanosheet & $\begin{array}{l}\text { Nanosheets containing latanoprost }(2.5 \mathrm{mg} / \mathrm{cm}) \text { were given to rats for } 7 \mathrm{~d} \\
\text { with no evidence of local side effects, and a } 20 \text { percent reduction in IOP. }\end{array}$ & [150] \\
\hline Glaucoma & Latanoprost & Contact Lenses & $\begin{array}{l}\text { According to the in vivo animal study, contact lenses with } 40-45 \mathrm{~mm} \text { thick } \\
\text { polymer-drug films (latanoprost) produced an initial burst of latanoprost } \\
\text { in aqueous humor, followed by a steady-state concentration comparable to } \\
\text { the average hourly concentration of latanoprost induced by a decrease in } \\
\text { commercially available latanoprost. }\end{array}$ & [133] \\
\hline Glaucoma & $\begin{array}{l}\text { Acetazolamide, } \\
\text { Ethoxzolamide }\end{array}$ & Contact Lenses & $\begin{array}{l}\text { Biomimetic networks can load more drugs than conventionally synthesized } \\
\text { pHEMA hydrogels, and monitor better drug release. } \\
\text { The biomimetic hydrogels were incredibly cytocompatible, making them } \\
\text { excellent for application as medicated soft contact lenses or oxygen- } \\
\text { permeable inserts. }\end{array}$ & {$[151]$} \\
\hline Cataracts & $\begin{array}{l}\text { Naproxen } \\
\text { sodium }\end{array}$ & Eye drop & $\begin{array}{l}\text { Due to poor AR inhibitory activity, naproxen has been reported to } \\
\text { postpone cataracts in diabetic rats }\end{array}$ & [152] \\
\hline
\end{tabular}


Table 3: Medication tested in clinical trials to treat an eye problem associated with diabetes

\begin{tabular}{lll}
\hline Disease & Drug & Approach \\
\hline Cataract & Ketorolac & Ophthalmic solution 0.4\% \\
Diabetic Retinopathy & Nevanac, ilevro & Suspension \\
Diabetic Retinopathy & Somatostatin & Eye drop \\
Glaucoma & Citicoline & Eye drop \\
\hline
\end{tabular}

\section{CONCLUSION}

Diabetes mellitus and associated ocular consequences continue to be a leading cause of blindness. As a result, our understanding of these ocular issues has improved, as has our ability to detect effective treatment. With early diagnosis and treatment, all diabetic ocular complications can be avoided. The pathophysiological aspect, treatment, and formulation strategy to diabetic cataracts, glaucoma, diabetic retinopathy, and macular edema are all addressed in this analysis.

\section{ACKNOWLEDGEMENT}

The authors are thankful to the Noida Institute of Engineering and Technology (Pharmacy Institute), Greater Noida-201 306, Uttar Pradesh, India, for providing all necessary support and facilities to conduct the survey related to the present review.

\section{FUNDING}

Nil

\section{ABBREVIATION}

DM: Diabetic Mellitus, DME: Diabetic Macular Edema, FDA: Food and Drug Administration, DR: Diabetic Retinopathy, ARI: Aldose Reductase Inhibitor, AGE: Advanced Glycation End-Product, IOP: Intraocular Pressure, PKC: Protein Kinase C, CAG: Closed Angle Glaucoma

\section{AUTHORS CONTRIBUTIONS}

All the authors have contributed equally.

\section{CONFLICTS OF INTERESTS}

The authors have reported no conflicts of interest.

\section{REFERENCES}

1. Kelkar A, Kelkar J, Mehta H, Amoaku W. Cataract surgery in diabetes mellitus: A systematic review. Indian J Ophthalmol. 2018 Oct;66(10):1401-10. doi: 10.4103/ijo.IJO_1158_17, PMID 30249823.

2. Kharroubi AT, Darwish HM. Diabetes mellitus: the epidemic of the century. World J Diabetes. 2015 Jun 25;6(6):850-67. doi: 10.4239/wjd.v6.i6.850, PMID 26131326.

3. Endris T, Worede A, Asmelash D. Prevalence of diabetes mellitus, prediabetes and its associated factors in Dessie Town, Northeast Ethiopia: A community-based study. Diabetes Metab Syndr Obes. 2019 Dec 31;12:2799-809. doi: 10.2147/DMSO.S225854, PMID 32021343.

4. Henriques J, Vaz Pereira S, Nascimento J, Rosa PC. [Diabetic eye disease]. Acta Med Port. 2015 Jan-Feb;28(1):107-13. doi: 10.20344/amp.5361, PMID 25817504.

5. Sayin N, Kara N, Pekel G. Ocular complications of diabetes mellitus. World J Diabetes. 2015 Feb 15;6(1):92-108. doi: 10.4239/wjd.v6.i1.92, PMID 25685281.

6. Wong TY, Cheung N, Tay WT, Wang JJ, Aung T, Saw SM, Lim SC, Tai ES, Mitchell P. Prevalence and risk factors for diabetic retinopathy: the Singapore Malay Eye Study. Ophthalmology. 2008 Nov;115(11):1869-75. doi: 10.1016/j.ophtha.2008. 05.014, PMID 18584872.

7. Kaur A, Gupta V, Christopher AF, Malik MA, Bansal P. Nutraceuticals in prevention of cataract- An evidence based approach. Saudi J Ophthalmol. 2017 Jan-Mar;31(1):30-7. doi: 10.1016/j.sjopt.2016.12.001, PMID 28337060.

8. Peterson SR, Silva PA, Murtha TJ, Sun JK. Cataract surgery in patients with diabetes: management strategies. Semin Ophthalmol. 2018;33(1):75-82. doi: 10.1080/08820538. 2017.1353817, PMID 29144826.
9. Hamid S, Gul A, Hamid Q. Relationship of cytokines and AGE products in diabetic and non-diabetic patients with cataract. Int J Health Sci (Qassim). 2016 Oct;10(4):507-15. doi: 10.12816/0048891, PMID 27833515.

10. Gupta D, Chen PP. Glaucoma. Am Fam Physician. 2016 Apr 15;93(8):668-74. PMID 27175839.

11. Kiziltoprak H, Tekin K, Inanc M, Goker YS. Cataract in diabetes mellitus. World J Diabetes. 2019 Mar 15;10(3):140-53. doi: 10.4239/wjd.v10.i3.140, PMID 30891150.

12. Chiou SH, Chang CJ, Chou CK, Hsu WM, Liu JH, Chiang CH. Increased nitric oxide levels in aqueous humor of diabetic patients with neovascular glaucoma. Diabetes Care. 1999 May;22(5):861-2. doi: 10.2337/diacare.22.5.861a, PMID 10332703.

13. Zghal I, Jeddi A, Hadj Alouane WB, Malouche N, Ayed S, Gaigi S. Primary open-angle glaucoma and diabetes [Primary openangle glaucoma and diabetes]. Tunis Med. 2000 Aug-Sep;78(89):518-21. PMID 11190730.

14. Sanders RJ, Wilson MR. Diabetes-related eye disorders. J Natl Med Assoc. 1993 Feb;85(2):104-8. PMID 8441184.

15. Stahl A. The diagnosis and treatment of age-related macular degeneration. Dtsch Arztebl Int. 2020 Jul 20;117(29-30):51320. doi: 10.3238/arztebl.2020.0513, PMID 33087239.

16. Jung HA, Islam MD, Kwon YS, Jin SE, Son YK, Park JJ, Sohn HS, Choi JS. Extraction and identification of three major aldose reductase inhibitors from Artemisia montana. Food Chem Toxicol. 2011 Feb;49(2):376-84. doi: 10.1016/j.fct.2010.11.012, PMID 21092751.

17. Thiagarajan G, Venu T, Balasubramanian D. Approaches to relieve the burden of cataracts blindness through natural antioxidants: use of Ashwagandha (Withania somnifera). Curr Sci. 2003;85:1065-71.

18. Kinoshita JH. A thirty year journey in the polyol pathway. Exp Eye Res. 1990 Jun;50(6):567-73. doi: 10.1016/00144835(90)90096-d, PMID 2115448.

19. Grewal AS, Bhardwaj S, Pandita D, Lather V, Sekhon BS. Updates on aldose reductase inhibitors for management of diabetic complications and non-diabetic diseases. Mini Rev Med Chem. 2016;16(2):120-62. doi: 10.2174/1389557515666150909143737, PMID 26349493.

20. Julius A, Hopper W. Inhibition of advanced glycation endproduct formation by quercetin and catechin: an alternative therapy for treating diabetic complications. Asian J Pharm Clin Res. $2017 \quad$ Nov;10(11):173-6. doi: 10.22159/ajpcr.2017.v10i11.19412.

21. Dixit BL, Balendiran GK, Watowich SJ, Srivastava S, Ramana KV, Petrash JM, Bhatnagar A, Srivastava SK. Kinetic and structural characterization of the glutathione-binding site of aldose reductase. J Biol Chem. 2000 Jul 14;275(28):21587-95. doi: 10.1074/jbc.M909235199, PMID 10764810.

22. Alexiou P, Pegklidou K, Chatzopoulou M, Nicolaou I, Demopoulos VJ. Aldose reductase enzyme and its implication to major health problems of the 21(st) century. Curr Med Chem. 2009;16(6):734-52. doi: 10.2174/092986709787458362, PMID 19199934.

23. Yan SF, Ramasamy R, Naka Y, Schmidt AM. Glycation, inflammation, and RAGE: a scaffold for the macrovascular complications of diabetes and beyond. Circ Res. 2003 Dec 12;93(12):1159-69. doi: 10.1161/01.RES.0000103862.26506.3D, PMID 14670831.

24. Srivastava S, Ramana KV, Tammali R, Srivastava SK, Bhatnagar A. Contribution of aldose reductase to diabetic hyperproliferation of vascular smooth muscle cells. Diabetes. 2006 Apr;55(4):901-10. doi: 10.2337/diabetes.55.04.06.db05-0932, PMID 16567509.

25. Ramana KV, Friedrich B, Srivastava S, Bhatnagar A, Srivastava SK. Activation of nuclear factor-kappaB by hyperglycemia in vascular smooth muscle cells is regulated by aldose reductase. 
Diabetes. 2004 Nov;53(11):2910-20. doi: 10.2337/ diabetes.53.11.2910, PMID 15504972.

26. Ahmed N. Advanced glycation endproducts--role in pathology of diabetic complications. Diabetes Res Clin Pract. 2005 Jan;67(1):321. doi: 10.1016/j.diabres.2004.09.004, PMID 15620429.

27. Stitt AW. The Maillard reaction in eye diseases. Ann N Y Acad Sci. 2005 Jun;1043:582-97. doi: 10.1196/annals.1338.066, PMID 16037281.

28. Ornek K, Karel F, Buyukbingol Z. May nitric oxide molecule have a role in the pathogenesis of human cataract? Exp Eye Res. 2003 Jan;76(1):23-7. doi: 10.1016/s0014-4835(02)00268-3, PMID 12589772.

29. Nagaraj RH, Linetsky M, Stitt AW. The pathogenic role of maillard reaction in the aging eye. Amino Acids. 2012 Apr;42(4):1205-20. doi: 10.1007/s00726-010-0778-x, PMID 20963455.

30. Agarwal R, Gupta SK, Agarwal P, Saxena R, Agrawal SS. Current concepts in the pathophysiology of glaucoma. Indian J Ophthalmol. 2009 Jul-Aug;57(4):257-66. doi: 10.4103/03014738.53049, PMID 19574692.

31. Lee DA, Higginbotham EJ. Glaucoma and its treatment: a review. Am J Health Syst Pharm. 2005 Apr 1;62(7):691-9. doi: 10.1093/ajhp/62.7.691, PMID 15790795.

32. Dimitrioua CD, DC. Pathophysiology of glaucoma. Future Medicine Ltd.; 2013.

33. Kaushik S, Pandav SS, Ram J. Neuroprotection in glaucoma. J Postgrad Med. 2003 Jan-Mar;49(1):90-5. doi: 10.4103/00223859.917, PMID 12865582.

34. Quigley HA, Nickells RW, Kerrigan LA, Pease ME, Thibault DJ, Zack DJ. Retinal ganglion cell death in experimental glaucoma and after axotomy occurs by apoptosis. Invest Ophthalmol Vis Sci. 1995 Apr;36(5):774-86. PMID 7706025.

35. Cavet ME, Vittitow JL, Impagnatiello F, Ongini E, Bastia E. Nitric oxide (NO): an emerging target for the treatment of glaucoma. Invest Ophthalmol Vis Sci. 2014 Aug 14;55(8):5005-15. doi: 10.1167/iovs.14-14515, PMID 25125670.

36. Pacher P, Beckman JS, Liaudet L. Nitric oxide and peroxynitrite in health and disease. Physiol Rev. 2007 Jan;87(1):315-424. doi: 10.1152/physrev.00029.2006, PMID 17237348.

37. Wong VH, Bui BV, Vingrys AJ. Clinical and experimental links between diabetes and glaucoma. Clin Exp Optom. 2011 Jan;94(1):4-23. doi: 10.1111/j.1444-0938.2010.00546.x, PMID 21091536.

38. Kuehn MH, Fingert JH, Kwon YH. Retinal ganglion cell death in glaucoma: mechanisms and neuroprotective strategies. Ophthalmol Clin North Am. 2005 Sep;18(3):383-95, vi. doi: 10.1016/j.ohc.2005.04.002, PMID 16054996.

39. Pendergast SD. Vitrectomy for diabetic macular edema associated with a taut premacular posterior hyaloid. Curr Opin Ophthalmol. 1998 Jun;9(3):71-5. doi: 10.1097/00055735199806000-00013, PMID 10182105.

40. Witmer AN, Vrensen GF, Van Noorden CJ, Schlingemann RO. Vascular endothelial growth factors and angiogenesis in eye disease. Prog Retin Eye Res. 2003 Jan;22(1):1-29. doi: 10.1016/s1350-9462(02)00043-5, PMID 12597922.

41. Josh Z, Yuen OD. Reconsider your approach to diabetic retionopathy. Rev Optom. 2015 Jun:28-9.

42. Miyamoto K, Khosrof S, Bursell SE, Rohan R, Murata T, Clermont AC, Aiello LP, Ogura Y, Adamis AP. Prevention of leukostasis and vascular leakage in streptozotocin-induced diabetic retinopathy via intercellular adhesion molecule-1 inhibition. Proc Natl Acad Sci USA. 1999 Sep 14;96(19):1083641. doi: 10.1073/pnas.96.19.10836, PMID 10485912.

43. Ramasamy R, Vannucci SJ, Yan SS, Herold K, Yan SF, Schmidt AM. Advanced glycation end products and RAGE: a common thread in aging, diabetes, neurodegeneration, and inflammation. Glycobiology. 2005 Jul;15(7):16R-28R. doi: 10.1093/glycob/cwi053, PMID 15764591.

44. Wilkinson CP, Ferris FL 3rd, Klein RE, Lee PP, Agardh CD, Davis M, Dills D, Kampik A, Pararajasegaram R, Verdaguer JT, Global Diabetic Retinopathy Project Group. Proposed international clinical diabetic retinopathy and diabetic macular edema disease severity scales. Ophthalmology. 2003 Sep;110(9):167782. doi: 10.1016/S0161-6420(03)00475-5, PMID 13129861.
45. Tang J, Kern TS. Inflammation in diabetic retinopathy. Prog Retin Eye Res. 2011 Sep;30(5):343-58. doi: 10.1016/j.preteyeres.2011.05.002, PMID 21635964.

46. Wilkinson Berka JL, Agrotis A, Deliyanti D. The retinal reninangiotensin system: roles of angiotensin II and aldosterone. Peptides. $2012 \quad$ Jul;36(1):142-50. 10.1016/j.peptides.2012.04.008, PMID 22537944.

47. Gao S, Qin T, Liu Z, Caceres MA, Ronchi CF, Chen CY, Yeum KJ, Taylor A, Blumberg JB, Liu Y, Shang F. Lutein and zeaxanthin supplementation reduces $\mathrm{H} 2 \mathrm{O} 2$-induced oxidative damage in human lens epithelial cells. Mol Vis. 2011;17:3180-90. PMID 22194644.

48. Bruno G, Costantino L, Curinga C, Maccari R, Monforte F, Nicoló F, Ottanà R, Vigorita MG. Synthesis and aldose reductase inhibitory activity of 5-arylidene-2,4-thiazolidinediones. Bioorg Med Chem. 2002 Apr;10(4):1077-84. doi: 10.1016/s09680896(01)00366-2, PMID 11836118.

49. Pegklidou K, Nicolaou I, Demopoulos VJ. Nutritional overview on the management of type 2 diabetes and the prevention of its complications. Curr Diabetes Rev. 2010 Nov;6(6):400-9. doi: 10.2174/157339910793499083, PMID 20879970.

50. Chatzopoulou M, Alexiou P, Kotsampasakou E, Demopoulos VJ. Novel aldose reductase inhibitors: a patent survey (2006-present). Expert Opin Ther Pat. 2012 Nov;22(11):1303-23. doi: 10.1517/13543776.2012.726615, PMID 22998509.

51. Leuenberger PM. Diabetic cataract and flavonoids (first results) (author's transl) [Diabetic cataracts, and flavonoids (first results) (author's transl)]. Klin Monbl Augenheilkd. 1978 Apr;172(4):460-2. PMID 418268.

52. Huang R, Shi F, Lei T, Song Y, Hughes CL, Liu G. Effect of the isoflavone genistein against galactose-induced cataracts in rats. Exp Biol Med (Maywood). 2007 Jan;232(1):118-25. PMID 17202592.

53. Moghaddam MS, Kumar PA, Reddy GB, Ghole VS. Effect of Diabecon on sugar-induced lens opacity in organ culture: mechanism of action. J Ethnopharmacol. 2005 Feb 28;97(2):397-403. doi: 10.1016/j.jep.2004.11.032, PMID 15707781.

54. Matsumoto T, Ono Y, Kuromiya A, Toyosawa K, Ueda Y, Bril V. Long-term treatment with ranirestat (AS-3201), a potent aldose reductase inhibitor, suppresses diabetic neuropathy and cataract formation in rats. J Pharmacol Sci. 2008 Jul;107(3):340-8. doi: 10.1254/jphs.08071fp, PMID 18612195.

55. Mucke HAM, Mucke E, Mucke PM. Aldose reductase inhibitors for diabetic cataracts: A study of disclosure patterns in patents, and peer review papers. Ophthalmol res. Int J. 2014 Jan;2(3):137-49.

56. Jaiswal S. Ss T, Mishra S. Neuroprotective effect of epalrestat on memory impairment in streptozotocin-induced type-2 diabetic rats using different behavioral models. Asian J Pharm Clin Res. 2018 Jan 1:411-5.

57. Suzen S, Buyukbingol E. Recent studies of aldose reductase enzyme inhibition for diabetic complications. Curr Med Chem. 2003 Aug;10(15):1329-52. doi: 10.2174/0929867033457377, PMID 12871133.

58. Kojima M, Sun L, Hata I, Sakamoto Y, Sasaki H, Sasaki K. Efficacy of alpha-lipoic acid against diabetic cataract in rat. Jpn J Ophthalmol. 2007 Jan-Feb;51(1):10-3. doi: 10.1007/s10384006-0384-3, PMID 17295134.

59. Durukan AH, Evereklioglu C, Hurmeric V, Kerimoglu $\mathrm{H}_{\text {, }}$ Erdurman C, Bayraktar MZ, Mumcuoglu T. Ingestion of IH636 grape seed proanthocyanidin extract to prevent seleniteinduced oxidative stress in experimental cataracts. J Cataract Refract Surg. 2006 Jun;32(6):1041-5. doi: 10.1016/j.jcrs.2006.02.041, PMID 16814068.

60. Biswas S, Harris F, Singh J, Phoenix D. Role of calpains in diabetes mellitus-induced cataractogenesis: a mini review. Mol Cell Biochem. 2004 Jun;261(1-2):151-9. doi: 10.1023/b:mcbi.0000028750.78760.6f, PMID 15362498.

61. McCord JM, Fridovich I. Superoxide dismutase. An enzymic function for erythrocuprein (hemocuprein). J Biol Chem. 1969 Nov 25;244(22):6049-55. doi: 10.1016/S00219258(18)63504-5, PMID 5389100

62. Yan Q, Liu JP, Li DW. Apoptosis in lens development and pathology. Differentiation. 2006 Jun;74(5):195-211. doi: 10.1111/j.1432-0436.2006.00068.x, PMID 16759286. 
63. Saelens X, Festjens N, Vande Walle L, van Gurp M, van Loo G, Vandenabeele P. Toxic proteins released from mitochondria in cell death. Oncogene. 2004 Apr 12;23(16):2861-74. doi: 10.1038/sj.onc.1207523, PMID 15077149.

64. Schreck R, Albermann K, Baeuerle PA. Nuclear factor kappa B: an oxidative stress-responsive transcription factor of eukaryotic cells (a review) [a review]. Free Radical Res Commun. 1992;17(4):221-37. 10.3109/10715769209079515, PMID 1473734

65. Doganay S, Borazan M, Iraz M, Cigremis Y. The effect of resveratrol in experimental cataract model formed by sodium selenite. Curr Eye Res. 2006 Feb;31(2):147-53. doi: 10.1080/02713680500514685, PMID 16500765.

66. Papucci L, Schiavone N, Witort E, Donnini M, Lapucci A, Tempestini A, Formigli L, Zecchi-Orlandini S, Orlandini G, Carella G, Brancato R, Capaccioli S. Coenzyme q10 prevents apoptosis by inhibiting mitochondrial depolarization independently of its free radical scavenging property. J Biol Chem. 2003 Jul 25;278(30):28220-8. doi: $10.1074 /$ jbc.M302297200, PMID 12736273.

67. McCarthy S, Somayajulu M, Sikorska M, Borowy-Borowski H, Pandey S. Paraquat induces oxidative stress and neuronal cell death; neuroprotection by water-soluble Coenzyme Q10. Toxicol Appl Pharmacol. 2004 Nov 15;201(1):21-31. doi: 10.1016/j.taap.2004.04.019, PMID 15519605.

68. Giacco F, Brownlee M. Oxidative stress and diabetic complications. Circ Res. 2010 Oct 29;107(9):1058-70. doi: 10.1161/CIRCRESAHA.110.223545, PMID 21030723.

69. Monnier VM, Cerami A. Non-enzymatic glycosylation and browning of proteins in diabetes. Clin Endocrinol Metab. 1982 Jul;11(2):431-52. doi: 10.1016/s0300-595x(82)80023-6, PMID 6754164 .

70. Clifford MN. Chlorogenic acids and other cinnamates- nature, occurrence, dietary burden, absorption and metabolism. J Sci Food Agric. 2000;80(7):1033-43. doi: 10.1002/(SICI)10970010(20000515)80:7<1033::AID-JSFA595>3.0.C0;2-T.

71. Morimitsu Y, Yoshida K, Esaki S, Hirota A. Protein glycation inhibitors from thyme (Thymus vulgaris). Biosci Biotechnol Biochem. 1995 Nov;59(11):2018-21. doi: 10.1271/bbb.59.2018, PMID 8541639.

72. Javadi MA, Zarei-Ghanavati S. Cataracts in diabetic patients: a review article. J Ophthalmic Vis Res. 2008 Jan;3(1):52-65. PMID 23479523.

73. Schmidl D, Schmetterer L, Garhofer G, Popa-Cherecheanu A. Pharmacotherapy of glaucoma. J Ocul Pharmacol Ther. 2015 Mar;31(2):63-77. doi: 10.1089/jop.2014.0067, PMID 25587905.

74. Arthur S, Cantor LB. Update on the role of alpha-agonists in glaucoma management. Exp Eye Res. 2011 Sep;93(3):271-83. doi: 10.1016/j.exer.2011.04.002, PMID 21524649.

75. Toris CB, Koepsell SA, Yablonski ME, Camras CB. Aqueous humor dynamics in ocular hypertensive patients. J Glaucoma. 2002 Jun;11(3):253-8. doi: 10.1097/00061198-20020600000015, PMID 12140404.

76. Kalapesi FB, Coroneo MT, Hill MA. Human ganglion cells express the alpha-2 adrenergic receptor: relevance to neuroprotection. Br J Ophthalmol. 2005 Jun;89(6):758-63. doi: 10.1136/bjo.2004.053025, PMID 15923515.

77. Grieshaber MC, Flammer J. Is the medication used to achieve the target intraocular pressure in glaucoma therapy of relevance?--an exemplary analysis on the basis of two betablockers. Prog Retin Eye Res. 2010 Jan;29(1):79-93. doi: 10.1016/j.preteyeres.2009.08.002, PMID 19733652.

78. Pfeiffer N, Lamparter J, Gericke A, Grus FH, Hoffmann EM, Wahl J. Neuroprotection of medical IOP-lowering therapy. Cell Tissue Res. 2013 Aug;353(2):245-51. doi: 10.1007/s00441-013-16711, PMID 23836043.

79. Sambhara D, Aref AA. Glaucoma management: relative value and place in therapy of available drug treatments. Ther Adv Chronic Dis. 2014 Jan;5(1):30-43. doi: 10.1177/2040622313511286, PMID 24381726.

80. Kaur IP, Smitha R, Aggarwal D, Kapil M. Acetazolamide: future perspective in topical glaucoma therapeutics. Int J Pharm. 2002 Nov 6;248(1-2):1-14. doi: 10.1016/s0378-5173(02)00438-6, PMID 12429455.
81. Alagöz N, Tellioglu A, Bektasoglu DL, Yasar T, Basgil Pasaoglu I, Altan AC, Solmaz B, Basarır B. Do we conform with European glaucoma society guidelines in the medical treatment of primary open-angle glaucoma/ocular hypertension? Data from a real-life practice. J Ocul Pharmacol Ther. 2020 Dec;36(10):747-53. doi: 10.1089/jop.2020.0032, PMID 33326338.

82. Weinreb RN, Toris CB, Gabelt BT, Lindsey JD, Kaufman PL. Effects of prostaglandins on the aqueous humor outflow pathways. Surv Ophthalmol. 2002 Aug;47;Suppl 1:S53-64. doi: 10.1016/s0039-6257(02)00306-5, PMID 12204701.

83. Kumar B, Gupta SK, Saxena R, Srivastava S. Current trends in the pharmacotherapy of diabetic retinopathy. J Postgrad Med. 2012 Apr-Jun;58(2):132-9. doi: 10.4103/0022-3859.97176, PMID 22718058.

84. Al Rashaed S, Arevalo JF. Combined therapy for diabetic macular edema. Middle East Afr J Ophthalmol. 2013 OctDec;20(4):315-20. doi: 10.4103/0974-9233.120014, PMID 24339681.

85. Cho WB, Moon JW, Kim HC. Intravitreal triamcinolone and bevacizumab as adjunctive treatments to panretinal photocoagulation in diabetic retinopathy. Br J Ophthalmol. 2010 Jul;94(7):858-63. doi: 10.1136/bjo.2009.168997, PMID 20606024.

86. Daull P, Paterson CA, Kuppermann BD, Garrigue JS. A preliminary evaluation of dexamethasone palmitate emulsion: a novel intravitreal sustained delivery of corticosteroid for treatment of macular edema. J Ocul Pharmacol Ther. 2013 Mar;29(2):258-69. doi: 10.1089/jop.2012.0044, PMID 23331052.

87. Fung WE. The national, prospective, randomized vitrectomy study for chronic aphakic cystoid macular edema. Progress report and comparison between the control and nonrandomized groups. Progress report. Surv Ophthalmol. 1984 May;28;Suppl:569-75. doi: 10.1016/0039-6257(84)90240-6, PMID 6463852.

88. Tapp RJ, Shaw JE, Harper CA, de Courten MP, Balkau B, McCarty DJ, Taylor HR, Welborn TA, Zimmet PZ, AusDiab Study Group. The prevalence of and factors associated with diabetic retinopathy in the Australian population. Diabetes Care. 2003 Jun;26(6):1731-7. doi: 10.2337/diacare.26.6.1731, PMID 12766102.

89. Sfikakis PP, Markomichelakis N, Theodossiadis GP, Grigoropoulos $\mathrm{V}$, Katsilambros N, Theodossiadis PG. Regression of sightthreatening macular edema in type 2 diabetes following treatment with the anti-tumor necrosis factor monoclonal antibody infliximab. Diabetes Care. 2005 Feb;28(2):445-7. doi: 10.2337/diacare.28.2.445, PMID 15677814.

90. Ferrara N, Hillan KJ, Gerber HP, Novotny W. Discovery and development of bevacizumab, an anti-VEGF antibody for treating cancer. Nat Rev Drug Discov. 2004 May;3(5):391-400. doi: 10.1038/nrd1381, PMID 15136787.

91. Spielberg L, Leys A. Treatment of neovascular age-related macular degeneration with a variable ranibizumab dosing regimen and one-time reduced-fluence photodynamic therapy: the TORPEDO trial at 2 years. Graefes Arch Clin Exp Ophthalmol. 2010 Jul;248(7):943-56. doi: 10.1007/s00417009-1256-6, PMID 20204659.

92. Matsumiya W, Honda S, Otsuka K, Miki A, Nagai T, Imai $H$, Kusuhara S, Nakamura M. Comparison of the effectiveness and prognostic factors of intravitreal ranibizumab between typical neovascular age-related macular degeneration and polypoidal choroidal vasculopathy over 24 months of follow-Up. Ophthalmologica. 2015 Jun;234(1):33-9. doi: 10.1159/000431000, PMID 26112059.

93. Siegel AB, Goyal A, Salomao M, Wang S, Lee V, Hsu C, Rodriguez R, Hershman DL, Brown RS Jr, Neugut AI, Emond J, Kato T, Samstein B, Faleck D, Karagozian R. Serum adiponectin is associated with worsened overall survival in a prospective cohort of hepatocellular carcinoma patients. Oncology. 2015;88(1):57-68. doi: 10.1159/000367971, PMID 25300295.

94. Takahashi K, Saishin Y, Saishin Y, King AG, Levin R, Campochiaro PA. Suppression and regression of choroidal neovascularization by the multitargeted kinase inhibitor pazopanib. Arch Ophthalmol. 2009 Apr;127(4):494-9. doi: 10.1001/archophthalmol.2009.27, PMID 19365030.

95. Kuppermann BD, Thomas EL, de Smet MD, Grillone LR, Vitrase for Vitreous Hemorrhage Study Groups. Safety results of two 
phase III trials of an intravitreous injection of highly purified ovine hyaluronidase (Vitrase) for the management of vitreous hemorrhage. Am J Ophthalmol. 2005 Oct;140(4):585-97. doi: 10.1016/j.ajo.2005.06.022, PMID 16226510.

96. Papadopoulos KP, Siegel DS, Vesole DH, Lee P, Rosen ST, Zojwalla N, Holahan JR, Lee S, Wang Z, Badros A. Phase I study of 30-minute infusion of carfilzomib as single agent or in combination with low-dose dexamethasone in patients with relapsed and/or refractory multiple myeloma. J Clin Oncol. 2015 Mar 1;33(7):732-9. doi: 10.1200/JCO.2013.52.3522, PMID 25225420.

97. Halim EM, Mukhopadhyay AK. Effect of ocimum sanctum (Tulsi) and vitamin $\mathrm{E}$ on biochemical parameters and retinopathy in streptozotocin induced diabetic rats. Indian J Clin Biochem. 2006 Sep;21(2):181-8. doi: 10.1007/BF02912939, PMID 23105641.

98. Agrawal SS, Naqvi S, Gupta SK, Srivastava S. Prevention and management of diabetic retinopathy in STZ diabetic rats by Tinospora cordifolia and its molecular mechanisms. Food Chem Toxicol. $2012 \quad$ Sep;50(9):3126-32. doi: 10.1016/j.fct.2012.05.057, PMID 22687550.

99. Wang CZ, Basila D, Aung HH, Mehendale SR, Chang WT, McEntee E, Guan X, Yuan CS. Effects of ganoderma lucidum extract on chemotherapy-induced nausea and vomiting in a rat model. Am J Chin Med. 2005;33(5):807-15. doi: 10.1142/S0192415X05003429, PMID 16265993.

100. Gupta SK, Kumar B, Nag TC, Agrawal SS, Agrawal R, Agrawal P, Saxena R, Srivastava S. Curcumin prevents experimental diabetic retinopathy in rats through its hypoglycemic, antioxidant, and antiinflammatory mechanisms. J Ocul Pharmacol Ther. 2011 Apr;27(2):123-30. doi: 10.1089/jop.2010.0123, PMID 21314438.

101. Steigerwalt R, Belcaro G, Cesarone MR, Di Renzo A, Grossi MG, Ricci A, Dugall M, Cacchio M, Schönlau F. Pycnogenol improves microcirculation, retinal edema, and visual acuity in early diabetic retinopathy. J Ocul Pharmacol Ther. 2009 Dec;25(6):537-40. doi: 10.1089/jop.2009.0023, PMID 19916788.

102. Kumar VL, Padhy BM. Protective effect of aqueous suspension of dried latex of Calotropis procera against oxidative stress and renal damage in diabetic rats. Biocell. 2011 Dec;35(3):63-9. doi: 10.32604/biocell.2011.35.063, PMID 22423482.

103. Chen Y, Li XX, Xing NZ, Cao XG. Quercetin inhibits choroidal and retinal angiogenesis in vitro. Graefes Arch Clin Exp Ophthalmol. 2008 Mar;246(3):373-8. doi: 10.1007/s00417-007-0728-9, PMID 18087712.

104. Nathiya S, Durga M, Devasena T. Quercetin, encapsulated quercetin, and its application- A review. Int J Pharm Pharm Sci. 2014 Oct;6(10):20-6.

105. Kowluru RA, Atasi L, Ho YS. Role of mitochondrial superoxide dismutase in the development of diabetic retinopathy. Invest Ophthalmol Vis Sci. 2006 Apr;47(4):1594-9. doi: 10.1167/iovs.05-1276, PMID 16565397.

106. Matthews DR, Stratton IM, Aldington SJ, Holman RR, Kohner EM, UK Prospective Diabetes Study Group. Risks of progression of retinopathy and vision loss related to tight blood pressure control in type 2 diabetes mellitus: UKPDS 69. Arch Ophthalmol. 2004 Nov;122(11):1631-40. doi: 10.1001/archopht.122.11.1631, PMID 15534123.

107. Kim JH, Lee BJ, Kim JH, Yu YS, Kim KW. Anti-angiogenic effect of caffeic acid on retinal neovascularization. Vasc Pharmacol. 2009 Oct;51(4):262-7. doi: 10.1016/j.vph.2009.06.010, PMID 19589397.

108. Kowluru RA, Odenbach S. Effect of long-term administration of alpha-lipoic acid on retinal capillary cell death and the development of retinopathy in diabetic rats. Diabetes. 2004 Dec;53(12):3233-8. doi: 10.2337/diabetes.53.12.3233, PMID 15561955.

109. Petersen M, Simmonds MS. Rosmarinic acid. Phytochemistry. 2003 Jan;62(2):121-5. doi: 10.1016/s0031-9422(02)00513-7, PMID 12482446.

110. Hammes HP, Du X, Edelstein D, Taguchi T, Matsumura T, Ju Q, Lin J, Bierhaus A, Nawroth P, Hannak D, Neumaier M, Bergfeld R, Giardino I, Brownlee M. Benfotiamine blocks three major pathways of hyperglycemic damage and prevents experimental diabetic retinopathy. Nat Med. 2003 Mar;9(3):294-9. doi: 10.1038/nm834, PMID 12592403.
111. Moustafa SA. Zinc might protect oxidative changes in the retina and pancreas at the early stage of diabetic rats. Toxicol Appl Pharmacol. 2004 Dec 1;201(2):149-55. doi: 10.1016/j.taap.2004.05.014, PMID 15541754.

112. Lal VK, Verma A. Development and evaluation of ophthalmic drop and in-situ gel from roots of boerhaavia diffusa. BJPR. 2016 Mar 21;11(1):1-20. doi: 10.9734/BJPR/2016/24395.

113. Velpandian T, Nirmal J, Gupta P, Vijayakumar AR, Ghose S. Evaluation of calcium dobesilate for its anti-cataract potential in experimental animal models. Methods Find Exp Clin Pharmacol. $2010 \quad$ Apr;32(3):171-9. doi: $10.1358 / \mathrm{mf} 2010.32 .3 .1423888$, PMID 20448859.

114. Jonnalagadd VG, Selkar N. Antidiabetic herbal products marketed in India: an update. J Med Plants Stud. 2013;1(6):24-6.

115. Tanito M, Hara K, Takai Y, Matsuoka Y, Nishimura N, Jansook P, Loftsson T, Stefánsson E, Ohira A. Topical dexamethasonecyclodextrin microparticle eye drops for diabetic macular edema. Invest Ophthalmol Vis Sci. 2011 Oct 10;52(11):7944-8. doi: 10.1167/iovs.11-8178, PMID 21896859.

116. Mazzolani F, Togni S, Giacomelli L, Eggenhoffner R, Franceschi F. Oral administration of a curcumin-phospholipid formulation (Meriva ${ }^{\circledR}$ ) for treatment of chronic diabetic macular edema: a pilot study. Eur Rev Med Pharmacol Sci. 2018 Jun;22(11):361725. doi: 10.26355/eurrev_201806_15189, PMID 29917217.

117. Chae JB, Joe SG, Yang SJ, Lee JY, Sung KR, Kim JY, Kim JG, Yoon $\mathrm{YH}$. Effect of combined cataract surgery and ranibizumab injection in postoperative macular edema in nonproliferative diabetic retinopathy. Retina. 2014 Jan;34(1):149-56. doi: 10.1097/IAE.0b013e3182979b9e, PMID 23807186.

118. Ragasa CY, Lorena GS, M, andia EH, Raga DD, Shen CC. Chemical constituents of Abrus precatorius. Am J Essent Oils Nat Prod. 2013;1(2):7-10.

119. Radha MH, Laxmipriya NP. Evaluation of biological properties and clinical effectiveness of Aloe vera: A systematic review. J Tradit Complement Med. 2015;5(1):21-6. doi: 10.1016/j.jtcme.2014.10.006, PMID 26151005.

120. Narayana DB, Durg S, Manohar PR, Mahapatra A, Aramya AR. Chyawanprash: A review of therapeutic benefits as in authoritative texts and documented clinical literature. J Ethnopharmacol. $2017 \quad$ Feb 2;197:52-60. doi: 10.1016/j.jep.2016.07.078, PMID 27496580.

121. Boti JB, Koukoua G, N'Guessan TY, Casanova J. Chemical variability ofConyza sumatrensis andMicroglossa pyrifolia from Côte d'Ivoire. Flavour Fragr J. 2007 Jan;22(1):27-31. doi: 10.1002/ffj.1743.

122. Kaur IP, Singh M, Kanwar M. Formulation and evaluation of ophthalmic preparations of acetazolamide. Int J Pharm. 2000 Apr 20;199(2):119-27. doi: 10.1016/s0378-5173(00)00359-8, PMID 10802405.

123. Crim N, Velez Montoya R, Morales Canton V. Surgical versus medical treatment for diabetic macular edema: a review. Med Hypothesis Discov Innov Ophthalmol. 2017 Winter;6(4):13642. PMID 29560368.

124. Callanan D, Williams P. Topical nepafenac in the treatment of diabetic macular edema. Clin Ophthalmol. 2008 Dec;2(4):68992. doi: 10.2147/opth.s3965, PMID 19668417.

125. Weisz JM, Bressler NM, Bressler SB, Schachat AP. Ketorolac treatment of pseudophakic cystoid macular edema identified more than 24 months after cataract extraction. Ophthalmology. 1999 Sep;106(9):1656-9. doi: 10.1016/S0161-6420(99)903664, PMID 10485530.

126. Kataria P, Katara R, Sahoo PK, Sachdeva S. Dorzolamide in situ gel forming system: characterization and evaluation for glaucoma treatment. Madridge J Pharm Res. 2017;1(1):13-21. doi: $10.18689 / \mathrm{mjpr}-1000103$.

127. Mortazavi SA, Jafariazar Z, Ghadjahani Y, Mahmoodi H, Mehtarpour F. Formulation and in vitro characterization of sustained release matrix type ocular timolol maleate minitablet. Iran J Pharm Res. 2014;13(1):19-27. PMID 24734053.

128. Emad Eldeeb A, Salah S, Ghorab M. Proniosomal gel-derived niosomes: an approach to sustain and improve the ocular delivery of brimonidine tartrate; formulation, in vitro characterization, and in vivo pharmacodynamic study. Drug Deliv. 2019 Dec;26(1):509-21. doi: 10.1080/ 10717544.2019.1609622, PMID 31090464. 
129. Dubey A, Prabhu P. Formulation and evaluation of stimulisensitive hydrogels of timolol maleate and brimonidine tartrate for the treatment of glaucoma. Int J Pharm Investig. 2014 Jul;4(3):112-8. doi: 10.4103/2230-973X.138340, PMID 25126524.

130. Alvarez Rivera F, Concheiro A, Alvarez Lorenzo C. Epalrestatloaded silicone hydrogels as contact lenses to address diabeticeye complications. Eur J Pharm Biopharm. 2018 Jan;122:12636. doi: 10.1016/j.ejpb.2017.10.016, PMID 29079419.

131. Ali Z, Sharma PK, Warsi MH. Fabrication and evaluation of ketorolac loaded cubosome for ocular drug delivery. J App Pharm Sci. 2016 Sep;6(09):204-8. doi: 10.7324/JAPS.2016.60930.

132. Huang J, Peng T, Li Y, Zhan Z, Zeng Y, Huang Y, Pan X, Wu CY, Wu C. Ocular cubosome drug delivery system for timolol maleate: preparation, characterization, cytotoxicity, ex vivo, and in vivo evaluation. AAPS PharmSciTech. 2017 Nov;18(8):291926. doi: 10.1208/s12249-017-0763-8, PMID 28429294.

133. Meza Rios A, Navarro Partida J, Armendariz Borunda J, Santos A. Therapies based on nanoparticles for eye drug delivery. Ophthalmol Ther. 2020 Sep;9(3):1-14. doi: 10.1007/s40123020-00257-7, PMID 32383107.

134. Natarajan JV, Ang M, Darwitan A, Chattopadhyay S, Wong TT, Venkatraman SS. Nanomedicine for glaucoma: liposomes provide sustained release of latanoprost in the eye. Int J Nanomed. 2012;7:123-31. doi: 10.2147/IJN.S25468, PMID 22275828.

135. Li H, Liu Y, Zhang Y, Fang D, Xu B, Zhang L, Chen T, Ren K, Nie Y, Yao S, Song X. Liposomes as a novel ocular delivery system for brinzolamide: In vitro and in vivo studies. AAPS PharmSciTech. 2016 Jun;17(3):710-7. doi: 10.1208/s12249-015-0382-1, PMID 26335415.

136. Katiyar S, Pandit J, Mondal RS, Mishra AK, Chuttani K, Aqil M, Ali A, Sultana Y. In situ gelling dorzolamide loaded chitosan nanoparticles for the treatment of glaucoma. Carbohydr Polym. 2014 Feb 15;102:117-24. doi: 10.1016/j.carbpol.2013.10.079, PMID 24507263.

137. Warsi MH, Anwar M, Garg V, Jain GK, Talegaonkar S, Ahmad FJ, Khar RK. Dorzolamide-loaded PLGA/vitamin E TPGS nanoparticles for glaucoma therapy: pharmacoscintigraphy study and evaluation of extended ocular hypotensive effect in rabbits. Colloids Surf B Biointerfaces. 2014 Oct 1;122:423-31. doi: 10.1016/j.colsurfb.2014.07.004, PMID 25159319.

138. Jain K, Kumar RS, Sood S, Dhyanandhan G. Betaxolol hydrochloride loaded chitosan nanoparticles for ocular delivery and their anti-glaucoma efficacy. Curr Drug Deliv. 2013 Oct;10(5):493-9. doi: 10.2174/1567201811310050001, PMID 23410069.

139. Ibrahim MM, Abd-Elgawad AE, Soliman OA, Jablonski MM. Novel topical ophthalmic formulations for management of glaucoma. Pharm Res. 2013 Nov;30(11):2818-31. doi: 10.1007/s11095-013-1109-1, PMID 23771565.

140. Wang F, Chen L, Jiang S, He J, Zhang X, Peng J, Xu Q, Li R. Optimization of methazolamide-loaded solid lipid nanoparticles for ophthalmic delivery using Box-Behnken design. J Liposome Res. 2014 Sep;24(3):171-81. doi: 10.3109/08982104.2014.891231, PMID 24611687.

141. El-Salamouni NS, Farid RM, El-Kamel AH, El-Gamal SS. Effect of sterilization on the physical stability of brimonidine-loaded solid lipid nanoparticles and nanostructured lipid carriers. Int J Pharm. 2015 Dec 30;496(2):976-83. doi: 10.1016/j.ijpharm.2015.10.043, PMID 26498372.

142. Leonardi A, Bucolo C, Drago F, Salomone S, Pignatello R. Cationic solid lipid nanoparticles enhance ocular hypotensive effect of melatonin in rabbit. Int J Pharm. 2015 Jan 15;478(1):180-6. doi: 10.1016/j.ijpharm.2014.11.032, PMID 25448580 .
143. Wang F, Chen L, Zhang D, Jiang S, Shi K, Huang Y, Li R, Xu Q. Methazolamide-loaded solid lipid nanoparticles modified with low-molecular weight chitosan for the treatment of glaucoma: in vitro and in vivo study. J Drug Target. 2014 Nov;22(9):84958. doi: 10.3109/1061186X.2014.939983, PMID 25045926.

144. Fahmy HM, Saad EAES, Sabra NM, El-Gohary AA, Mohamed FF, Gaber MH. Treatment merits of latanoprost/thymoquinoneEncapsulated liposome for glaucomatus rabbits. Int J Pharm. 2018 Sep 5;548(1):597-608. doi: 10.1016/j.ijpharm.2018.07.012, PMID 29997042.

145. Mokhtar Ibrahim M, Tawfique SA, Mahdy MM. Liposomal diltiazem $\mathrm{HCl}$ as ocular drug delivery system for glaucoma. Drug Dev Ind Pharm. 2014 Jun;40(6):765-73. doi: 10.3109/03639045.2013.783589, PMID 23570512.

146. Yu S, Wang QM, Wang X, Liu D, Zhang W, Ye T, Yang X, Pan W. Liposome incorporated ion sensitive in situ gels for opthalmic delivery of timolol maleate. Int J Pharm. 2015 Mar 1;480(12):128-36. doi: 10.1016/j.ijpharm.2015.01.032, PMID 25615987.

147. Gagandeep, Garg T, Malik B, Rath G, Goyal AK. Development and characterization of nano-fiber patch for the treatment of glaucoma. Eur J Pharm Sci. 2014 Mar 12;53:10-6. doi: 10.1016/j.ejps.2013.11.016, PMID 24333373.

148. Aburahma MH, Mahmoud AA. Biodegradable ocular inserts for sustained delivery of brimonidine tartarate: preparation and in vitro/in vivo evaluation. AAPS PharmSciTech. 2011 Dec;12(4):1335-47. doi: 10.1208/s12249-011-9701-3, PMID 21979886.

149. Fulgencio Gde O, Viana FA, Ribeiro RR, Yoshida MI, Faraco AG, Cunha Junior Ada S. New mucoadhesive chitosan film for ophthalmic drug delivery of timolol maleate: in vivo evaluation. J Ocul Pharmacol Ther. 2012 Aug;28(4):350-8. doi: 10.1089/jop.2011.0174, PMID 22320419.

150. Kashiwagi K, Ito K, Haniuda H, Ohtsubo S, Takeoka S. Development of latanoprost-loaded biodegradable nanosheet as a new drug delivery system for glaucoma. Invest Ophthalmol Vis Sci. 2013 Aug 19;54(8):5629-37. doi: 10.1167/iovs.129513, PMID 23868986

151. Ribeiro A, Veiga F, Santos D, Torres Labandeira JJ, Concheiro A, Alvarez-Lorenzo C. Bioinspired imprinted PHEMA-hydrogels for ocular delivery of carbonic anhydrase inhibitor drugs. Biomacromolecules. 2011 Mar 14;12(3):701-9. doi: 10.1021/bm101562v, PMID 21314109.

152. Hao X, Han Z, Zhu C. Topical composition for treating diabetic cataracts: a patent evaluation (W02015026380A1). Expert Opin Ther Pat. 2016 Jun;26(6):731-5. doi: 10.1517/13543776.2016.1163339, PMID 26967920.

153. Wittpenn JR, Silverstein S, Heier J, Kenyon KR, Hunkeler JD, Earl M, Acular LS for Cystoid Macular Edema (ACME) Study Group. A randomized, masked comparison of topical ketorolac $0.4 \%$ plus steroid vs steroid alone in low-risk cataract surgery patients. Am J Ophthalmol. 2008 0ct;146(4):554-60. doi: 10.1016/j.ajo.2008.04.036, PMID 18599019. ajo.2008.04.036.

154. Yuksel B, Karti O, Kusbeci T. Topical nepafenac for prevention of post-cataract surgery macular edema in diabetic patients: patient selection and perspectives. Clin Ophthalmol. 2017 Dec 11;11:2183-90. doi: 10.2147/OPTH.S132810, PMID 29269999.

155. Julius A, Hopper W. A non-invasive, multi-target approach to treat diabetic retinopathy. Biomed Pharmacother. 2019 Jan;109:708-15. doi: 10.1016/j.biopha.2018.10.185, PMID 30551523.

156. Rossetti L, Iester M, Tranchina L, Ottobelli L, Coco G, Calcatelli E, Ancona C, Cirafici P, Manni G. Can treatment with citicoline eyedrops reduce progression in glaucoma? The results of a randomized placebo-controlled clinical trial. J Glaucoma. 2020 Jul;29(7):513-20. doi: 10.1097/IJG.0000000000001565, PMID 32541370 . 